\title{
Fermented beverages based on Hylocereus lemairei (Hook.) fruits: Chemical characterization and antioxidant capacity evaluation
}

\author{
Bebidas fermentadas à base de frutas Hylocereus lemairei (Hook.): caracterização química e \\ avaliação da capacidade antioxidante \\ Bebidas de frutas fermentadas Hylocereus lemairei (Hook.): caracterización química y evaluación \\ de capacidad antioxidante
}

Received: 04/26/2021 | Reviewed: 05/06/2021 | Accept: 05/08/2021 | Published: 05/22/2021

\author{
Anne Caroline de Albuquerque Sales \\ ORCID: https://orcid.org/0000-0003-0036-6072 \\ Federal Institute of Education, Science and Technology of Amazonas, Brazil \\ E-mail: anneasales@gmail.com \\ Lizeth Mercedes Garcia Jaimes \\ ORCID: https://orcid.org/0000-0002-3226-8293 \\ Federal Institute of Education, Science and Technology of Amazonas, Brazil \\ E-mail: lizeth.921121@gmail.com \\ Marcos Batista Machado \\ ORCID: https://orcid.org/0000-0002-8791-4803 \\ Federal University of Amazonas, Brazil \\ E-mail: marcosmachado@ufam.edu.br \\ Edgar Aparecido Sanches \\ ORCID: https://orcid.org/0000-0002-1446-723X \\ Federal University of Amazonas, Brazil \\ E-mail: sanchesufam@ufam.edu.br \\ Pedro Henrique Campelo \\ ORCID: https://orcid.org/0000-0002-5137-0162 \\ Federal University of Amazonas, Brazil \\ E-mail: pedrocampelo@ufam.edu.br \\ Hileia dos Santos Barroso \\ ORCID: https://orcid.org/0000-0002-1903-7394 \\ Federal Institute of Education, Science and Technology of Amazonas, Brazil \\ E-mail: hileia.santos@ifam.edu.br \\ Lúcia Schuch Boeira \\ ORCID: https://orcid.org/0000-0002-5471-0978 \\ Federal Institute of Education, Science and Technology of Amazonas, Brazil \\ E-mail: lucia.boeira@ifam.edu.br \\ Jaqueline de Araújo Bezerra \\ ORCID: https://orcid.org/0000-0002-9168-9864 \\ Federal Institute of Education, Science and Technology of Amazonas, Brazil \\ E-mail: jaqueline.araujo@ifam.edu.br
}

\begin{abstract}
Hylocereus lemairei (Hook.) is a plant popularly known as pitaya-purple, whose fruits are known as dragon fruit. This paper aimed to carry out the physical-chemical and chemical characterization of fermented beverages based on $H$. lemairei fruits. Fermented beverages were elaborated using two different commercial yeasts of Saccharomyces cerevisiae [Biolievito Bayanus (BB) and Arom Cuvée (AC)] and were characterized by NMR. In addition, the antioxidant capacity (DPPH and ABTS) and Total Phenolic Content (TPC) based on the Folin Ciocalteu method were determined. According to the legislation, the fermented beverages from BB and AC showed alcoholic levels of 12.9 and $12.5 \%(\mathrm{v} / \mathrm{v})$ and $\mathrm{pH}$ of 3.9 and 3.8, respectively. The chemical compounds of both beverages were similar, whose major organic compounds are glycerol, myo-inositol, tyrosol, and citric and succinic acids. According to the DPPH and TPC evaluation, BB beverage $\left(248.3 \mu \mathrm{M} \mathrm{TE}\right.$ and $\left.117.6 \mathrm{mg} \mathrm{GAE} \mathrm{L}^{-1}\right)$ presented higher antioxidant capacity when compared to the $\mathrm{BC}$ beverage $\left(219.8 \mu \mathrm{M}\right.$ TE and $\left.108.4 \mathrm{mg} \mathrm{GAE} \mathrm{L}^{-1}\right)$. In the ABTS assay, both beverages were not statistically different $(p<0.05)$. Tyrosol may be responsible for increasing the antioxidant capacity and phenolic compounds content when compared to the control juice used to prepare fermented beverages.
\end{abstract}

Keywords: Pitaia-roxa; Dragon fruit; Biolievito Bayanus; Arom Cuvée; Tyrosol. 


\begin{abstract}
Resumo
Hylocereus lemairei (Hook.) É uma planta popularmente conhecida como pitaia-roxa, cujos frutos são conhecidos como fruta-do-dragão. Este trabalho teve como objetivo realizar a caracterização físico-química e química de bebidas fermentadas à base de frutos de $H$. lemairei. As bebidas fermentadas foram elaboradas a partir de duas diferentes leveduras comerciais de Saccharomyces cerevisiae [Biolievito Bayanus (BB) e Arom Cuvée (AC)] e caracterizadas por RMN. Além disso, foram determinadas a capacidade antioxidante (DPPH e ABTS) e o Conteúdo de Fenólicos Totais (CFT) pelo método de Folin Ciocalteu. De acordo com a legislação, os fermentados de BB e BC apresentaram teores alcoólicos de 12,9 e 12,5\% (v/v) e pH de 3,9 e 3,8, respectivamente. Os compostos químicos das bebidas elaboradas foram semelhantes, cujos principais compostos orgânicos são o glicerol, o mio-inositol, o tirosol e os ácidos cítrico e succínico. De acordo com a avaliação DPPH e CFT, a bebida BB $(248,3 \mu \mathrm{M} \mathrm{TE} \mathrm{e} \mathrm{117,6} \mathrm{mg} \mathrm{GAE} \mathrm{L-1)}$ apresentou maior capacidade antioxidante quando comparada à bebida BC $\left(219,8 \mu \mathrm{M}\right.$ TE e $108,4 \mathrm{mg}$ GAE $\left.\mathrm{L}^{-1}\right)$. No ensaio ABTS, essas bebidas não foram estatisticamente diferentes $(p<0,05)$. O tirosol pode ser responsável por aumentar a capacidade antioxidante e o conteúdo de compostos fenólicos em comparação com o suco controle usado para preparar bebidas fermentadas.
\end{abstract}

Palavras-chave: Pitaia-roxa; Fruta-do-dragão; Biolievito Bayanus; Arom Cuvée; Tirosol.

\title{
Resumen
}

Hylocereus lemairei (Hook.) es una planta conocida popularmente como pitaya-púrpura, cuyos frutos se conocen como fruta del dragón. Este trabajo tuvo como objetivo realizar la caracterización físico-química y química de bebidas fermentadas a base de frutos de $H$. lemairei. Las bebidas fermentadas fueron elaboradas utilizando dos levaduras comerciales diferentes de Saccharomyces cerevisiae [Biolievito Bayanus (BB) y Arom Cuvée (AC)] y se caracterizaron por RMN. Además, se determinó la capacidad antioxidante (DPPH y ABTS) y el Contenido Fenólico Total (TPC) por el método de Folin Ciocalteu. Según la legislación, las bebidas fermentadas de BB y BC presentaron parámetros físico-químicos con niveles alcohólicos de 12,9 y $12,5 \%$ (v/v) y pH de 3,9 y 3,8, respectivamente. Los compuestos químicos de las bebidas elaboradas fueron similares, cuyos principales compuestos orgánicos son glicerol, mioinositol, tirosol, ácidos cítrico y succínico. Según la evaluación de DPPH y TPC, la bebida BB $(248,3 \mu \mathrm{M}$ TE y 117,6 $\left.\mathrm{mg} \mathrm{GAE} \mathrm{L}^{-1}\right)$ fue más alta en comparación con la bebida BC (219,8 $\mu \mathrm{M}$ TE y 108,4 mg GAE L $\left.\mathrm{L}^{-1}\right)$. En el ensayo ABTS, estas bebidas no fueron estadísticamente diferentes $(p<0,05)$. El tirosol puede ser responsable de aumentar la capacidad antioxidante y el contenido de compuestos fenólicos en comparación con el jugo utilizado para preparar bebidas fermentadas.

Palabras clave: Pitaia-púrpura; Fruta del dragón; Biolievito Bayanus; Arom Cuvée; Tirosol.

\section{Introduction}

Fermented fruit is defined as a beverage with an alcoholic degree from 4 to $14 \%\left(\mathrm{v} / \mathrm{v}, 20^{\circ} \mathrm{C}\right)$. Alcoholic fermentation can be obtained from fresh and ripe fruits of a single species, as well as from the respective integral juice, concentrate or pulp (Brasil, 2009). The process of obtaining fermented fruits is very similar to the wine production process with different operations according to the fruit type. Alcoholic fermentation is a relatively efficient preservation process because it increases the shelf life of a food product and reduces refrigeration or other forms of preservation technology. This technique is suitable in remote areas, where other preservation technologies are not available or inaccessible (Battcock \& Azam-Ali, 1998).

The species from the family Cactaceae was possibly originated in North, Central and South America. The genus Hylocereus is native from the tropical deciduous forests in Mexico, Western India, Central America and northern South America. The species are known as pitaya, whose fruits are called dragon fruit in Asia. Pitaya enhanced the interest of the consumer because it is exotic and a source of vitamins and minerals. Interesting for fruit growers is mainly based on their high commercial value (Bastos et al., 2006; Fernandes et al., 2017; Nunes et al., 2014).

In order to add value to the fruit and elaborate a new beverage with attractive colors, the species Hylocereus lemairei (Hook.) Britton \& Rose from the Cactaceae family was selected. Its fruits are popularly known as pitaya-purple, pitaya-red, pitaia, pitaya, pitahya roja or dragon fruit. It is a succulent epiphyte species, and have been cultivated in different regions of Brazil, including the Amazon region. Its fruits are globose, red, berry-like and without thorns with purple fleshy pulp and black seeds. It has the same water-soluble pigment found in beet, known as betalain. These $N$-heterocyclic compounds are categorized as betacyanins (red-purple color) and betaxanthines (yellow-orange color), which are natural antioxidants (Herbach; Stintzing; Carle, 2004; Kinupp; Lorenzi, 2014; Nunes et al., 2014). 
This work aims to determine the physical-chemical parameters, as well as the chemical profiles of fermented beverages from $H$. lemairei fruits. These alcoholic beverages were prepared using two different commercial yeasts and the antioxidant capacity and total phenol content were determined.

\section{Methodology}

\subsection{Preparation of fermented beverages}

Hylocereus lemairei fruits were purchased at the Adolpho Lisboa Market (Manaus, Amazonas). Fruits were washed and sanitized with peracetic acid $\left(0.5 \mathrm{~g} \mathrm{~L}^{-1}\right)$, cut and processed in a blender to obtain the juice. The yeastt was prepared in a 1.0:1.4 ratio (fruit/water, $\mathrm{m} / \mathrm{v}$ ), chaptalized to $21^{\circ}$ Brix and the $\mathrm{pH}$ (3.5) was corrected using tartaric acid. Fermentation process were carried out in glass bottles equipped with an airlock valve and conducted at $20{ }^{\circ} \mathrm{C}$ by the commercial yeasts Biolievito Bayanus (BB) and Arom Cuvée (AC) (Biotecsul, Caxias do Sul).

The fermentation evolution was monitored at regular intervals by the Total Soluble Solids - TSS ( ${ }^{\circ}$ Brix). Racking was performed after fermentation at $20^{\circ} \mathrm{C}$, followed by vacuum filtration with diatomaceous earth. The fermentation was stored in glass bottles with synthetic stoppers (Boeira et al., 2020). The following physicochemical analyzes were carried out (density at $20^{\circ} \mathrm{C}, \mathrm{pH}$, alcohol content, total sugars, total acidity, volatile acidity, ash, and reduced dry extract) (Jacobson, 2006; Rizzon, 2010).

\section{2 ${ }^{1} \mathrm{H}$ NMR analysis of Hylocereus lemairei fermented beverages}

A juice aliquot $(550 \mu \mathrm{L})$ was mixed with $50 \mu \mathrm{L}$ of $\mathrm{D}_{2} \mathrm{O}\left(0.6 \mathrm{mM}\right.$ TMSP- $\left.d_{4}\right)$. After ethanol removal in the absence of light, the fermented beverages were solubilized in $600 \mu \mathrm{L}$ of $\mathrm{D}_{2} \mathrm{O}\left(0.6 \mathrm{mM}\right.$ TMSP- $\left.d_{4}\right)$. Samples were subjected to a Bruker ${ }^{\circledR}$ Avance IIIHD Nuclear Magnetic Resonance Spectrometer (11.74 T, BBFO Plus SmartProbe TM) at $298 \mathrm{~K}$. The ZGPR sequence was used for analyzing the samples and suppression of the residual water signal (4.8 ppm). The obtained spectra were processed by TopSpin ${ }^{\mathrm{TM}}$ 4.1.1 software. Chemical identification of the compounds was appropriately marked based on the chemical shift $\left(\delta_{\mathrm{H}}\right.$ and $\left.\delta_{\mathrm{C}}\right)$, coupling constant $(J$ in Hertz), and comparison with literature data.

\subsection{Evaluation antioxidant capacity and quantification of total phenols}

\subsubsection{Scavenging capacity of DPPH' and $\mathrm{ABTS}^{+}$radicals}

Juice and fermented beverage were subjected to the scavenging capacity of DPPH ${ }^{\cdot}$ and $\mathrm{ABTS}^{+{ }^{+}}$radicals and the determination of total phenols was based on methodologies with marginal modifications on a microplate reader (Molyneux, 2004; Re et al., 1999; Souza et al., 2020). For the DPPH assay, $10 \mu \mathrm{L}$ of the sample was added to $190 \mu \mathrm{L}$ of the DPPH solution $(60 \mu \mathrm{M})$ and incubated in a dark environment for $30 \mathrm{~min}$. Subsequently, the absorbances were read on a Microplate Reader at $515 \mathrm{~nm}$ (Epoch 2, Biotek). A standard Trolox curve from 100 to $500 \mu \mathrm{M}$ was obtained $\left(\mathrm{y}=-0.0007 \mathrm{x}+0.5322, \mathrm{R}^{2}=0.9999\right.$ ). For the ABTS assay, the sample was mixed with the ABTS solution (1:100) and incubated in a dark environment for 6 min. Subsequently, the absorbances were read in the same microplate reader at $734 \mathrm{~nm}$. A standard Trolox curve from 62.5 to 500 $\mu \mathrm{M}$ was made $\left(y=-0.0002 x+0.6374, R^{2}=0.9999\right)$. Results were expressed in micromolar of Trolox Equivalents $(\mu \mathrm{M} T \mathrm{TE})$. Measurements were performed in triplicate.

\subsubsection{Total Phenolic Content (TPC)}

For the TPC content evaluation, samples were added to the reaction mixture (1:1) of Folin Ciocalteu reagent and sodium bicarbonate $\left(6 \mathrm{~g} \mathrm{~L}^{-1}\right)$, kept in the dark for $90 \mathrm{~min}$ for further analysis on a microplate reader at $725 \mathrm{~nm}$ (Epoch 2, Biotek). The standard curve for gallic acid was performed from 7.8 to $500 \mu \mathrm{g} \mathrm{mL}-1$ ( $\left.\mathrm{y}=0.0043 \mathrm{x}+0.0289, \mathrm{R}^{2}=0.9999\right)$. 
Results were expressed in milligrams of Gallic Acid Equivalents per liter of a sample (mg GAE L ${ }^{-1}$ ) (Velioglu et al., 1998; Souza et al., 2020). This assay was performed in triplicate.

\subsection{Statistical analysis}

ANOVA (One-Way, Tukey's test, 95\% significance) and Test-T $(p<0.05)$ to evaluate the assays. Results were expressed as mean \pm standard deviation. The Minitab ${ }^{\circledR} 18.1$ software was employed in these analyses.

\section{Results and Discussion}

\subsection{Physicochemical Analysis}

The fermentation evolution was monitored by the content of TSS ( ${ }^{\circ}$ Brix) over time regular intervals. The end of fermentation was determined when the TSS content stabilized on two consecutive measurements in 17 days with a TSS of 6 for both fermented beverages (Figure 1).

Figure 1. Alcoholic fermentation curves of Hylocereus lemairei fruits.

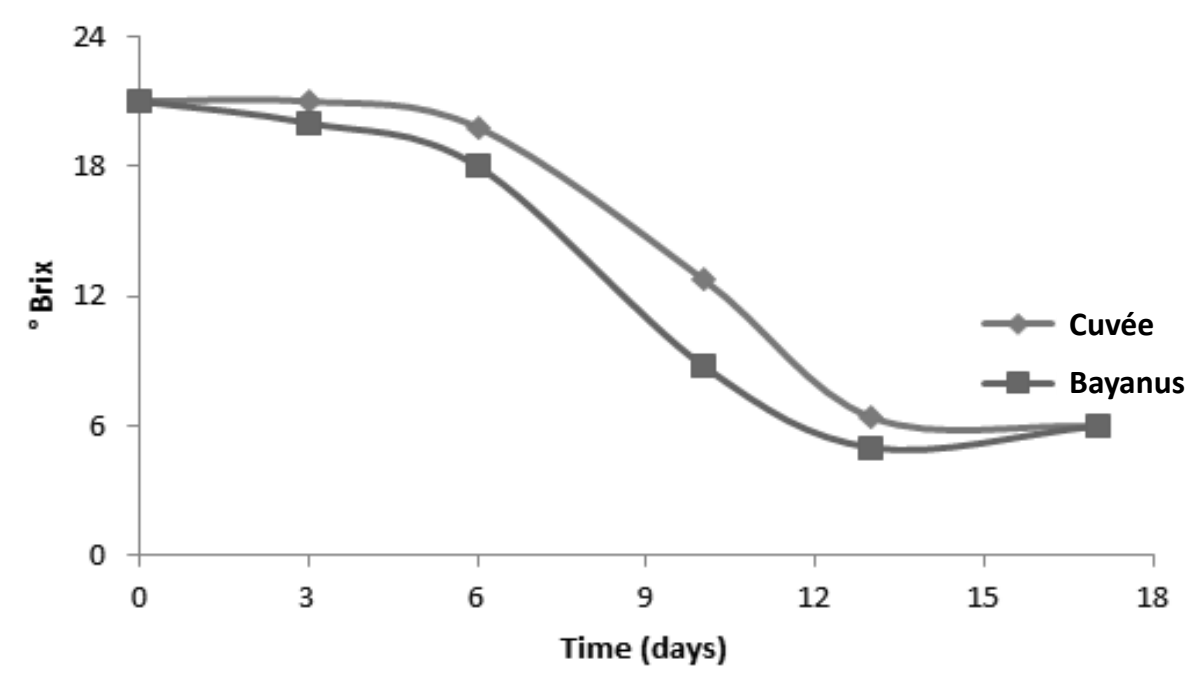

Source: Authors.

Then, fermented beverages from $H$. lemairei fruits were subjected to analysis of physical-chemical parameters (Table 1). The fermented products obtained from different yeasts presented an alcohol content within the range established by the current legislation from 4 to $14 \% \mathrm{v} / \mathrm{v}$, with 12.9 and $12.5 \%(\mathrm{v} / \mathrm{v})$ for the yeasts BB and AC, respectively. These densities were found to be similar among the fermented samples, $0.988 \mathrm{~g} \mathrm{~mL}^{-1}$. The $\mathrm{pH}$ of the beverage was 3.8 to 3.9. The values of total acidity in the beverage fermented by the yeasts $\mathrm{BB}$ and $\mathrm{AC}$ were $63.6 \mathrm{mEq} \mathrm{L}^{-1}$ and $62.1 \mathrm{mEq} \mathrm{L}^{-1}$, respectively. The acidity observed by current legislation for fermented fruit ranges from $50 \mathrm{mEq} \mathrm{L} \mathrm{L}^{-1}$ to $130 \mathrm{mEq} \mathrm{L}^{-1}$, so both fermented are in

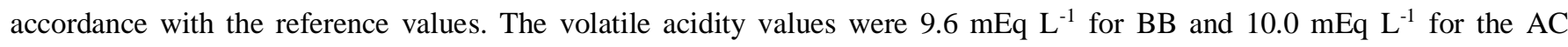
beverage, which are in agreement to the standards established by the legislation for fruit fermented (maximum $20.0 \mathrm{mEq} \mathrm{L}^{-1}$ ). The alcoholic beverages produced by the yeasts $\mathrm{BB}$ and $\mathrm{AC}$ showed dry extract content of $21.2 \mathrm{~g} \mathrm{~L}^{-1}$ and $20.7 \mathrm{~g} \mathrm{~L}^{-1}$, respectively. The ash concentration found in the AC beverage $\left(3.1 \mathrm{~g} \mathrm{~L}^{-1}\right)$ was slightly higher than that of $\mathrm{BB} 2.6 \mathrm{~g} \mathrm{~L}^{-1}$. The average ashes content for fermented beverages was found from 1 to $3 \mathrm{~g} \mathrm{~L}^{-1}$ (Brasil, 2012). 
Table 1. Results obtained for the physical-chemical parameters analyzed in the fermented beverages produced with Hylocereus lemairei fruits

\begin{tabular}{|c|c|c|c|c|c|c|c|}
\hline Sample & $\begin{array}{c}\text { alcohol } \\
\text { content }(\%)\end{array}$ & $\begin{array}{l}\text { density } \\
\left(\mathrm{g} \mathrm{mL}^{-1}\right)\end{array}$ & pH & $\begin{array}{l}\text { total acidity } \\
\left(\mathbf{m E q} \mathbf{L}^{-1}\right)\end{array}$ & $\begin{array}{c}\text { volatile } \\
\text { acidity } \\
\left(\mathbf{m E q} \mathbf{L}^{-1}\right)\end{array}$ & $\begin{array}{l}\text { dry extract } \\
\left(g \mathbf{L}^{-1}\right)\end{array}$ & $\begin{array}{c}\text { ash } \\
\left(g \mathbf{L}^{-1}\right)\end{array}$ \\
\hline BB & $12.9 \pm 0.1^{\mathrm{a}}$ & $0.99 \pm 0.00^{a}$ & $3.9 \pm 0.0^{\mathrm{a}}$ & $63.6 \pm 0.4^{\mathrm{a}}$ & $9.6 \pm 0.4^{\mathrm{a}}$ & $21.2 \pm 1.1^{\mathrm{a}}$ & $2.6 \pm 0.1^{b}$ \\
\hline $\mathbf{A C}$ & $12.5 \pm 0.2^{\mathrm{a}}$ & $0.99 \pm 0.00^{\mathrm{a}}$ & $3.8 \pm 0.0^{\mathrm{a}}$ & $62.1 \pm 0.6^{\mathrm{b}}$ & $10.0 \pm 0.4^{\mathrm{a}}$ & $20.7 \pm 1.2^{\mathrm{a}}$ & $3.1 \pm 0.3^{\mathrm{a}}$ \\
\hline
\end{tabular}

Resulted are expressed as means \pm standard deviation $(\mathrm{n}=3)$. ${ }^{\mathrm{a}-\mathrm{b}}$ Same letter in the same column are statically significant $(p$-value $<0.05)$. Source: Authors.

\section{2 ${ }^{1} \mathrm{H}$ NMR analysis of juices and fermented beverages}

The major signs characteristic of carbohydrates and organic acids were observed from the ${ }^{1} \mathrm{H}$ NMR spectrum (Figure 2, Table 2). The signals at $\delta_{\mathrm{H}} 5.23(\mathrm{~d}, J=3.8 \mathrm{~Hz})$ and at $\delta_{\mathrm{H}} 4.64(\mathrm{~d}, J=8.0 \mathrm{~Hz})$ were attributed to $\alpha$-glucose and $\beta$-glucose, respectively. The doublet in $\delta_{\mathrm{H}} 4.11(\mathrm{~J}=3.7 \mathrm{~Hz})$ and the multiplet in $\delta_{\mathrm{H}} 3.99$ were signed to fructose. The doublets at $\delta_{\mathrm{H}} 2.82$ and $\delta_{\mathrm{H}} 2.61(J=16.0 \mathrm{~Hz})$ were referred to the hydrogens of citric acid. The signals at $\delta_{\mathrm{H}} 4.34(\mathrm{dd}, J=8.8$ and $3.7 \mathrm{~Hz}), \delta_{\mathrm{H}} 2.75$ (dd, $J=15.7$ and $3.7 \mathrm{~Hz}$ ) and $\delta_{\mathrm{H}} 2.51(\mathrm{dd}, J=15.7$ and $8.8 \mathrm{~Hz}$ ) were attributed to malic acid. Data were compared with the scientific literature (Alves Filho et al., 2021).

Figure 2. ${ }^{1} \mathrm{H}$ NMR spectrum of Hylocereus lemairei juice $\left(\mathrm{H}_{2} \mathrm{O}: \mathrm{D}_{2} \mathrm{O}, 11.74 \mathrm{~T}\right)$.

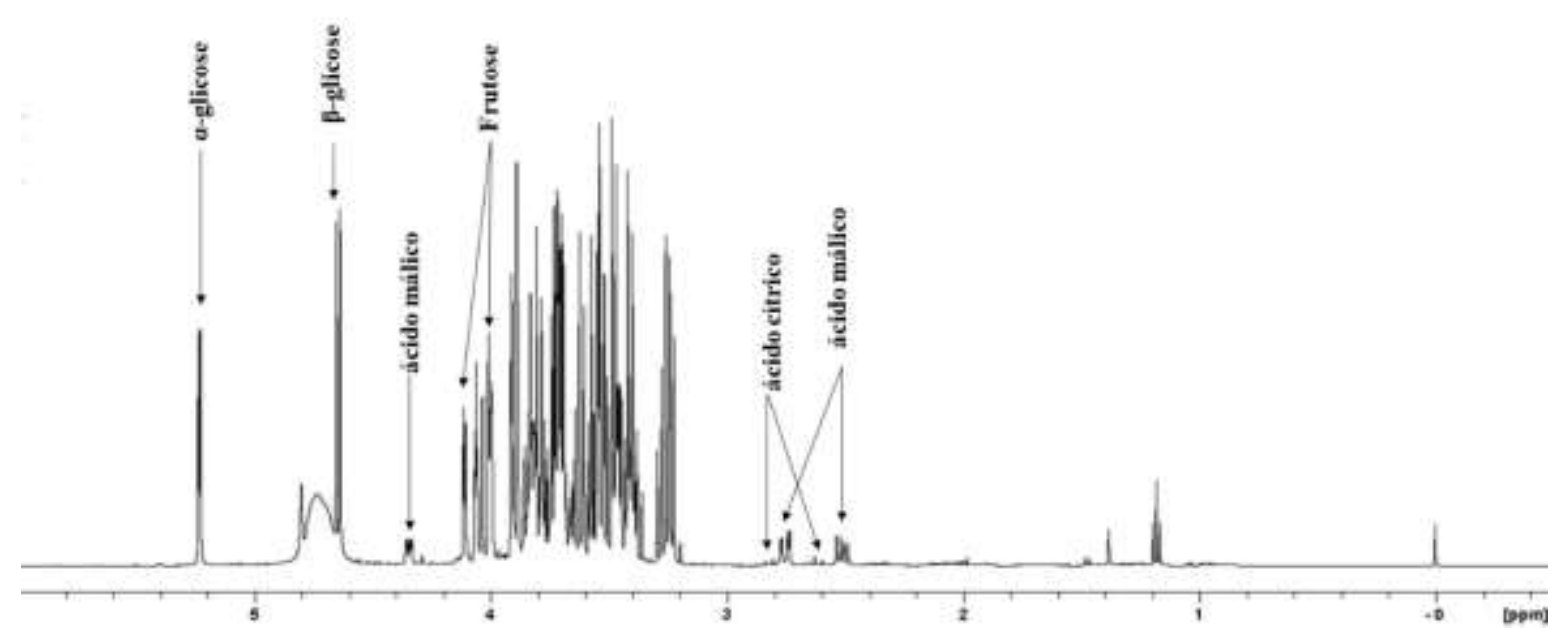

Source: Authors.

The analysis of chemical profiles by ${ }^{1} \mathrm{H}$ NMR of $H$. lemairei fermented beverage obtained with the BB and AC yeasts were similar (Figure 3, Table 2). The correlation maps HSQC and HMBC contributed to the confirmation of the compounds. The data were compared with the scientific literature (Al-Mekhlafi et al., 2021; Souza et al., 2020). After the fermentation process, no signs of sugars were observed, as there was a conversion to ethanol. After removed of ethanol, the analyzed extracts of both fermenters showed major signals of organic acids.

The signal at $\delta_{\mathrm{H}} 3.54(\mathrm{dd}, J=11.7$ and $6.5 \mathrm{~Hz})$ and at $\delta_{\mathrm{H}} 3.64(\mathrm{dd}, J=11.7$ and $4.3 \mathrm{~Hz})$ were directly linked to carbon at $\delta_{\mathrm{C}} 65.5$. The multiplet at $\delta_{\mathrm{H}} 3.77 \mathrm{ppm}$ linked to carbon at $\delta_{\mathrm{C}} 75.0 \mathrm{ppm}$ was attributed to glycerol. The signal at $\delta_{\mathrm{H}} 4.05 \mathrm{ppm}$ $(\mathrm{t}, J=2.9 \mathrm{~Hz})$ attached to carbon at $\delta_{\mathrm{C}} 75.1, \delta_{\mathrm{H}} 3.61(\mathrm{t}, J=9.5 \mathrm{~Hz}), \delta_{\mathrm{H}} 3.52(\mathrm{dd}, J=9.5$ and $2.9 \mathrm{~Hz})$ and $\delta_{\mathrm{H}} 3.26(\mathrm{t}, J=9.5 \mathrm{~Hz})$ was assigned to myo-inositol. The doublets at $\delta_{\mathrm{H}} 2.76$ and $\delta_{\mathrm{H}} 2.88(J=15.6 \mathrm{~Hz})$ linked to carbon in $\delta_{\mathrm{C}} 46.7$ was attributed to 
citric acid. The signal at $\delta_{\mathrm{H}} 2.62$ (s) attached to carbon at $\delta \mathrm{c} 32.5$ for succinic acid. Minority signals in the aromatic region, with the doublets in $\delta_{\mathrm{H}} 7.18(\mathrm{~d}, J=8.5 \mathrm{~Hz})$ and $\delta_{\mathrm{H}} 6.86(\mathrm{~d}, J=8.5 \mathrm{~Hz})$ linked to the respective carbons in $\delta_{\mathrm{C}} 133.4$ and $\delta_{\mathrm{C}}$ 118.4 were attributed to tyrosol.

The compounds glycerol, citric acid, and succinic acid were also found in the fermented beverage from dragon fruit (H. costaricensis). Higher glycerol content was observed in the fermentation with Saccharomyces cerevisiae when compared to different yeasts (Jiang et al., 2020). Glycerol is produced as a by-product of S. cerevisiae ethanolic fermentation process and is responsible for the smoothness and viscosity of wine (Scanes et al., 1998). Inositol has previously been identified in dragon fruit varieties (Al-Mekhlafi et al., 2021), which was not observed in the juice but was identified as one of the major coumpounds in fermented beverages.

Tyrosol is produced by Saccharomyces cerevisiae from L-tyrosine, anaerobically in the essential presence of glucose (Sentheshanmuganathan \& Elsden, 1958). Beer and wine are beverages containing tyrosol. When these beverages are consumed, this simple phenolic compound is converted endogenously to hydroxytyrosol. This phenolic compound has been considered a powerful antioxidant in diets (Soldevila-Domenech et al., 2019). Temperature, alcoholic degree, sugar and amino acid concentrations, oxygen dissolved and $\mathrm{pH}$ have been influenced the glycerol biosynthesis, as well as in the production of aromatic compounds (Bordiga et al., 2016; Zhao; Procopio; Becker, 2015).

Figure 3. ${ }^{1} \mathrm{H}$ NMR spectra of Hylocereus lemairei fermented beverages extracts $\left(\mathrm{D}_{2} \mathrm{O}, 11.74 \mathrm{~T}\right)$.

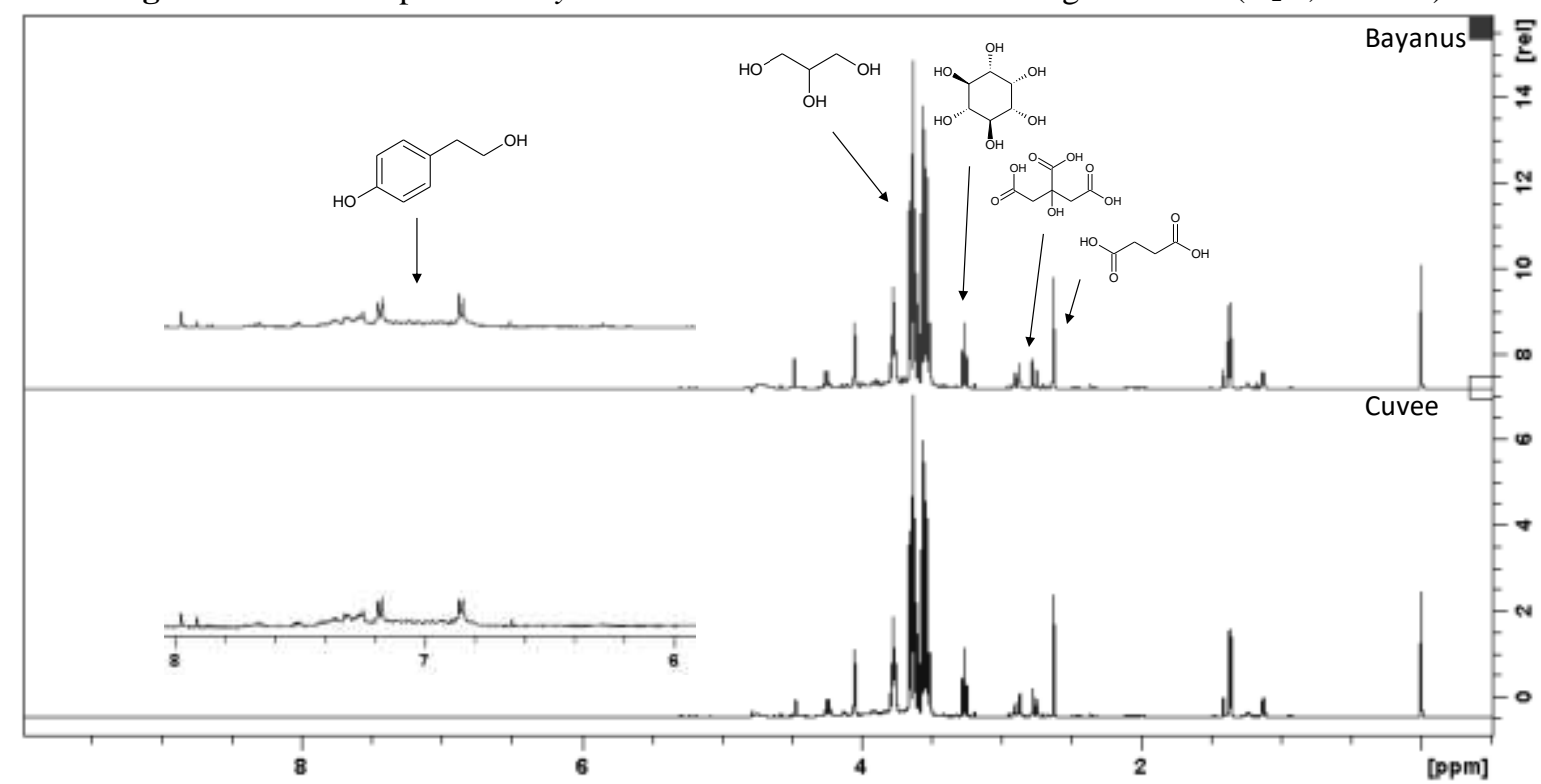

Source: Authors. 
Table 2. Compounds identified in the Hylocereus lemairei juice and fermented beverages extracts.

\begin{tabular}{|c|c|c|c|}
\hline \multirow{2}{*}{$\begin{array}{l}\text { Compounds } \\
\text { Structure }\end{array}$} & \multirow[b]{2}{*}{ Name } & \multicolumn{2}{|l|}{$\begin{array}{l}\text { NMR Data } \\
\end{array}$} \\
\hline & & $\begin{array}{c}\delta_{\mathrm{H}} \text { in ppm } \\
(\text { multiplicity and coupling in } \mathrm{Hz})^{*}\end{array}$ & $\delta \mathrm{c}$ in $\mathrm{ppm}$ \\
\hline \multicolumn{4}{|c|}{ Juice } \\
\hline & malic acid & $\begin{array}{c}2.51(d d, J=15.7 \text { and } 8.8) \\
2.75(d d, J=15.7 \text { and } 3.7) \\
4.34(d d, J=8.8 \text { and } 3.7)\end{array}$ & $\begin{array}{l}44.1,72.4 \\
181.0,182.9\end{array}$ \\
\hline & $\alpha$-glucose & $\begin{array}{c}5.23(d, J=3.8), 3.89(\mathrm{~m}) \\
3.77(\mathrm{~m}), 3.45(\mathrm{~m}), 3.71(\mathrm{~m}) \\
3.83(\mathrm{~m})\end{array}$ & $\begin{array}{l}95.1,72.6,75.7 \\
72.7,63.8,74.3\end{array}$ \\
\hline & $\beta$-glucose & $\begin{array}{c}4.64(d, J=8.0), 3.24(\mathrm{dd}, 9.1 \text { and } 8.0) \\
3.74(\mathrm{~m}), 3.47(\mathrm{~m}), 3.40(\mathrm{~m}), 3.90(\mathrm{~m})\end{array}$ & $\begin{array}{l}98.9,77.2,63.6 \\
78.7,72.6,63.7\end{array}$ \\
\hline & fructose & $\begin{array}{c}4.11(\mathrm{~d}, J=3.7), 3.82(\mathrm{~m}) \\
3.80(\mathrm{~m}), 3.67(\mathrm{~m}), 3.57(\mathrm{~m})\end{array}$ & $\begin{array}{c}77.8,83.5,65.3 \\
\quad 65.7,65.7\end{array}$ \\
\hline \multicolumn{4}{|c|}{ Beverages extracts } \\
\hline & L-alanine & $\begin{array}{c}1.36(\mathrm{~d}, J=7.0) \\
4.24(\mathrm{q})\end{array}$ & $\begin{array}{l}22.6,70.5 \\
183.6\end{array}$ \\
\hline & citric acid & $\begin{array}{l}2.88(d, J=15.6) \\
2.76(d, J=15.6)\end{array}$ & $\begin{array}{l}46.7,77.0 \\
177.9,181.8\end{array}$ \\
\hline & succinic acid & $2.62(\mathrm{~s})$ & $32.5,180.9$ \\
\hline & glycerol & $\begin{array}{c}3.54(\mathrm{dd}, 11.7 \text { and } 6.5), \\
3.64(\mathrm{dd}, 11.7 \text { and } 4.3), 3.77(\mathrm{~m})\end{array}$ & $65.5,75.0$ \\
\hline & myo-inositol & $\begin{array}{c}3.26(\mathrm{t}, J=9.5), 3.52(\mathrm{dd}, J=9.5 \text { and } 2.9) \\
3.61(\mathrm{t}, J=9.5) \\
4.05(\mathrm{t}, J=2.9)\end{array}$ & $\begin{array}{c}77.3,74.1,75.3 \\
75.1\end{array}$ \\
\hline & tyrosol & $6.86(\mathrm{~d}, J=8.5), 7.18(\mathrm{~d}, J=8.5)$ & $133.4,118.4$ \\
\hline
\end{tabular}

*Multiplicity: s, simplet; d, duplet; m, multiplet; dd, double duplet; q = quadruplet; triplet. Source: Authors.

\subsection{Antioxidant capacity and quantification of total phenols}

The results from the antioxidant capacity based on the DPPH and ABTS assays, as well as the quantification of the total phenols are shown in the Table 3. A significant increase of the amount of total phenols was observed in the fermented beverages when compared to the control juice used for their production. Pearson's correlations of DPPH' and ABTS ${ }^{+}$radical 
scavenging capacity assays were 0.900 ( $p$-value $<0.05$ ). The DPPH and ABTS assays showed excellent Pearson correlations with the total phenols assay: 0.985 and 0.952 ( $p$-value $<0.05$ ), respectively.

The scavenging capacity of the radicals observed from the DPPH and ABTS assays, as well as the presence of phenolic compounds in the fermented beverages can be attributed to the presence of the phenolic compound tyrosol (Souza et al., 2020). The content of phenolic compounds found in the fermented beverages was higher when compared to the fermented beverage with dragon fruit of $28.0 \mathrm{mg} \mathrm{GAE} \mathrm{L}^{-1}$ elaborated by Souza and contributors (2018), and lower when compared to the fermented beverage from dragon fruit (H. costaricensis) of $280.6 \mathrm{mg} \mathrm{GAE} \mathrm{L}^{-1}$ (Jiang et al., 2020).

Table 3. Results of DPPH, ABTS and TPC assays from Hylocereus lemairei beverages.

\begin{tabular}{|c|c|c|c|}
\hline Samples & $\begin{array}{c}\text { DPPH } \\
(\mu \mathrm{M} \text { TE })\end{array}$ & $\begin{array}{c}\text { ABTS } \\
(\mu \mathrm{M} \text { TE })\end{array}$ & $\begin{array}{c}\text { TPC } \\
\left(\mathrm{mg} \mathrm{GAE} \mathrm{L}^{-1}\right)\end{array}$ \\
\hline juice & $150 \pm 5^{c}$ & $167 \pm 10^{b}$ & $56 \pm 2^{c}$ \\
\hline BB beverage & $248 \pm 3^{\mathrm{a}}$ & $269 \pm 22^{a}$ & $118 \pm 4^{\mathrm{a}}$ \\
\hline AC beverage & $220 \pm 7^{b}$ & $280 \pm 8^{\mathrm{a}}$ & $108 \pm 3^{\mathrm{b}}$ \\
\hline
\end{tabular}

Resulted are expressed as means \pm standard deviation $(n=3)$. a-c Different letters in same column
are significant ( $p$-value $<0.05$ ). $\mu \mathrm{M}$ TE $=$ micromolar of Trolox equivalent, $\mathrm{mg} \mathrm{L}^{-1} \mathrm{GAE}=$ milligram of Gallic acid equivalent per liter of sample. Source: Authors.

\section{Conclusion}

The physical-chemical parameters analyzed in the Hylocereus lemairei fermented beverages prepared with the yeasts $\mathrm{BB}$ and $\mathrm{AC}$ are in accordance with the current legislation. The chemical profiles of the beverage extracts prepared with yeasts were similar, presenting as major compounds alcohols and organic acids, and phenolic compounds in lower concentration. Tyrosol, a phenolic compound, is probably responsible for the antioxidant capacity of the fermented beverages, when compared to the control juice. There was a significant increase in the antioxidant activity after the fermentation process. Future research must be carried out to evaluate the influence of different parameters in the preparation of $H$. lemairei fermented beverages. The production of new fermented beverage from fruits encourages the cultivation by communities in the capital and interior of Amazonas State, as well as contributes to the formation of local productive arrangements.

\section{Acknowledgments}

The authors thank the Analytical Center of Amazonas Federal University (UFAM) for the support on NMR analysis, as well as IFAM (Edital nº 01/2019 PADCIT/PR PPGI/IFAM) and Fundação de Amparo à Pesquisa do Estado do Amazonas (FAPEAM) for the financial support (grant number 062.01076/2018 - Universal/FAPEAM).

\section{References}

Al-Mekhlafi, N. A., Mediani, A., Ismail, N. H., Abas, F., Dymerski, T., Lubinska-Szczygeł, M., Vearasilp, S., \& Gorinstein, S. (2021). Metabolomic and antioxidant properties of different varieties and origins of Dragon fruit. Microchemical Journal, 160, 105687. https://doi.org/10.1016/j.microc.2020.105687

Alves Filho, E. G., Silva, L. M. A., de Brito, E. S., Castro, D. R. G., Bezerra, J. A., Sanches, E. A., Rodrigues, S., Fernandes, F. A. N., \& Campelo, P. H. (2021). Effect of Glow and Dielectric Barrier Discharges Plasma on Volatile and Non-volatile Chemical Profiling of Camu-Camu Juice. Food and Bioprocess Technology. https://doi.org/10.1007/s11947-021-02639-6

Bastos, D. C., Pio, R., Scarpare Filho, J. A., Libardi, M. N., Almeida, L. F. P. de, Galuchi, T. P. D., \& Bakker, S. T. (2006). Propagação da Pitaya "vermelha" por estaquia. Ciência e Agrotecnologia, 30(6), 1106-1109. https://doi.org/10.1590/s1413-70542006000600009

Battcock, M., \& Azam-Ali, S. (1998). Fermented frutis and vegetables. A global perspective. Table of contents. Food and Agriculture Organization of the United Nations Rome. http://www.fao.org/3/x0560e/x0560e00.htm\#con

Boeira, L. S., Bastos Freitas, P. H., Uchôa, N. R., Bezerra, J. A., Cád, S. V., Junior, S. D., Albuquerque, P. M., Mar, J. M., Ramos, A. S., Machado, M. B., \& Maciel, L. R. (2020). Chemical and sensorial characterization of a novel alcoholic beverage produced with native acai (Euterpe precatoria) from different regions of the Amazonas state. Lwt, 117(August 2019), 108632. https://doi.org/10.1016/j.lwt.2019.108632 
Bordiga, M., Lorenzo, C., Pardo, F., Salinas, M. R., Travaglia, F., Arlorio, M., Coïsson, J. D., \& Garde-Cerdán, T. (2016). Factors influencing the formation of histaminol, hydroxytyrosol, tyrosol, and tryptophol in wine: Temperature, alcoholic degree, and amino acids concentration. Food Chemistry, 197, 1038-1045. https://doi.org/10.1016/j.foodchem.2015.11.112

Brasil. (2009). Decreto $n^{\circ}$ 6.871, de 4 de junho de 2009. (p. 50). https://www.gov.br/agricultura/pt-br/assuntos/inspecao/produtos-vegetal/legislacao1/biblioteca-de-normas-vinhos-e-bebidas/decreto-no-6-871-de-4-de-junho-de-2009.pdf/view

Brasil. (2012). Instrução Normativa no 34, de 29 de novembro de 2012. In Ministério da Agricultura, Pecuária e Abastecimento (pp. 1-9). https://www.gov.br/agricultura/pt-br/assuntos/vigilancia-agropecuaria/ivegetal/bebidas-arquivos/in-no-34-de-29-de-novembro-de-2012.pdf/view

Fernandes, L. M. de S., Vieites, R. L., Lima, G. P. P., Braga, C. de L., \& Amaral, J. L. do. (2017). Caracterização do fruto de pitaia orgânica. Biodiversidade, $16(1), 167-178$.

Herbach, M. K., Stintzing, F. C., \& Carle, R. (2004). Thermal degradation of betacyanins in juices from purple pitaya [Hylocereus polyrhizus (Weber) Brittonv \& Rose] monitored by high-performance liquid chromatography-tandem mass spectometric analyses. European Food Research and Technology, 219(4), 377-385. https://doi.org/10.1007/s00217-004-0948-8

Jacobson, J. L. (2006). Introduction to wine laboratory practices and procedures. In Introduction to Wine Laboratory Practices and Procedures (1st ed.). Springer. https://doi.org/10.1007/0-387-25120-0

Jiang, X., Lu, Y., \& Liu, S. Q. (2020). Effects of Different Yeasts on Physicochemical and Oenological Properties of Red Drag on Fruit Wine Fermented with Saccharomyces cerevisiae, Torulaspora delbrueckii and Lachancea thermotolerans. Microorganisms, 315 , https://doi.org/10.3390/microorganisms8030315

Kinupp, V. F., \& Lorenzi, H. H. (2014). Plantas Alimenticias não convencionais (PANC) no Brasil: guia de identificação, aspectos nutricionais e receitas ilustradas. (1st ed.). Instituto Plantarum.

Molyneux, P. (2004). The use of the stable free radical diphenylpicryl- hydrazyl (DPPH) for estimating antioxidant activity. Songklanakarin J. Sci. Technol., $50(2)$

Nunes, E. N., Sandro, A., Sousa, B. De, Lucena, C. M. De, Silva, S. D. M., Farias, R., Lucena, P. De, Antônio, C., Alves, B., \& Alves, E. (2014). Pitaia (Hylocereus sp.): Uma revisão para o Brasil Ernane. Gaia Scientia, 8(1), 90-98.

Re, R., Pellegrini, N., Proteggente, A., Ananth, P., Yng, M., \& Rice-Evans, C. (1999). Antioxidant Activity applying an improved ABTS radical cation decolorization assay. Free Radical Biology \& Medicine, 26(9-10), 1231-1237.

Rizzon, L. A. (2010). Metodologia para análise de vinho (L. A. Rizzon (ed.); 1st ed.). Embrapa Informação Tecnológica. http://www.embrapa.br/liv

Scanes, K. T., Hohmann, S., \& Prior, B. . (1998). Glycerol production by the yeast Saccharomyces and its relevance to wine: A Review. South African Journal of Enology and Viticulture, 19(1), 8 .

Sentheshanmuganathan, S., \& Elsden, S. R. (1958). The mechanism of the formation of tyrosol by Saccharomyces cerevisiae. The Biochemical Journal, 69(2), 210-218. https://doi.org/10.1042/bj0690210

Soldevila-Domenech, N., Boronat, A., Mateus, J., Diaz-Pellicer, P., Matilla, I., Pérez-Otero, M., Aldea-Perona, A., \& De La Torre, R. (2019). Generation of the antioxidant hydroxytyrosol from tyrosol present in beer and red wine in a randomized clinical trial. Nutrients, 11(9), 1-14. https://doi.org/10.3390/nu11092241

Souza, A. C. L., Ramos, A. S., Mar, J. M., Boeira, L. S., de Bezerra, J. A., \& Machado, M. B. (2020). Alcoholic beverages from araçá-boi fruit: quantification of antioxidant compounds by NMR ERETIC2. Journal of Food Science and Technology, 57(12), 4733-4738. https://doi.org/10.1007/s13197-020-04721-x

Souza, A. C. de, Fernandes, A. C. F., Silva, M. S., Schwan, R. F., \& Dias, D. R. (2018). Antioxidant activities of tropical fruit wines. Journal of the Institute of Brewing, 124(4), 492-497. https://doi.org/10.1002/jib.511

Velioglu, Y. S., Mazza, G., Gao, L., \& Oomah, B. D. (1998). Antioxidant Activity and Total Phenolics in Selected Fruits, Vegetables, and Grain Products. Journal of Agricultural and Food Chemistry, 46(10), 4113-4117. https://doi.org/10.1021/jf9801973

Zhao, X., Procopio, S., \& Becker, T. (2015). Flavor impacts of glycerol in the processing of yeast fermented beverages: a review. Journal of Food Science and Technology, 52(12), 7588-7598. https://doi.org/10.1007/s13197-015-1977-y 